\title{
The Role and Function of the Antonyms in Language
}

\author{
Ph.D. Candidate/ Ekaterina Strati Gjergo \\ Aleksander Moisiu University Durres, Faculty of Education \\ Department of Foreign Languages \\ ekaterina_gjergo@yahoo.co.uk
}

Prof.Dr.as. Shpresa Delija

University of Tirana, Faculty of Foreign Languages

Department of English Language

delija.sh@gmail.com

\section{Doi:10.5901/mjss.2014.v5n16p703}

\section{Abstract}

In this paper we will discuss in detail the role and functions of antonyms in language and speech. The practical importance of antonyms relies on their understanding in use of everyday life communicational situations. Even though the linguistic explanation is important and fundamental, it helps for other disciplines to understand better situations and circumstances when antonyms are used. Their misuse can cause a lot of misunderstandings and cultural clashes. In this theoretical approach to antonyms and their importance in use this article will stop on the handling and the role they perform and in another part of the paper will focus on their functions in discourse.

Keywords: role, function, antonyms, communicational situations

\section{The Role of Antonyms}

The practical importance of antonyms relies on their understanding in use of everyday life communicational situations. Even though the linguistic explanation is important and fundamental, it helps for other disciplines to understand better situations and circumstances when antonyms are used. Their misuse can cause a lot of misunderstandings and cultural clashes.

Croft notes that: "antonym has more powerful relationship between lexicon-semantic relations." Antonyms from native speakers are use intuitively in all walks of life. Antonym plays an important role in several fields of study, such as linguistics, psychology, literature or psycholinguistics and language acquisition in children. It is used to express binary opposition in all modalities and communication registers as spoken language in the writing, as to the facts as well as fiction, as the in the standard and unofficial use of language.

First, the role of linguistics in particular antonyms shown clearly their ability to better explain the meaning of the words clearly analogous or bilingual dictionaries. So, the contribution in the field of lexicography is of particular importance. In the field of linguistics, antonyms serve as a source of enrichment of the Albanian language through wordformation, namely through the establishment of antonymic couples with the same root as the word-grammar by means of prefixes and rarely, in cases of stylistic antonyms, through suffixes.

Secondly, the connection with psychological antonyms can be linked with studies associating the word (wordassociation) through which detects when the human mind is able to function in relation to countering.

Thirdly, in the field of literature, opposites are analysed as distinguishing features of dramatic prose. Even literary figures often are influenced by broader role of antonym. It also underlies such phrases as "Timid men prefer calm despotism to the tempestuous sea of liberty" aimed at emphasizing and clarifying the idea and the message given. Thus, it serves as a powerful tool in argumentation, narrative, explanation and description.

Moreover, it is also important in the process of language acquisition. In this process it shows interest the fact of antonyms stored since early childhood. It is documented that children from an early age tend to perceive the concept of opposition by teaching antonyms in pairs with more than one at a time. Kagan notes that immediately after the child learns the word "up" and "down" or immediately after the word "good", the meaning of the word "bad". This may be related to what Lyons calls "the tendency to dichotomy". However, it may simply be a learning strategy used by children as part 
of a general mechanism in language acquisition. Practice seems to learn words in a family of similar meaning is simple. However, Jones stresses that "pairs of words which simply appropriated the children are obviously antonyms". Antonym occupies an important place in lexicography as well as lexicographic works which is centred on language learners.

M.Samara states that "antonym (as well as synonyms and polysemy) enhances and strengthens the expressive character of political and social vocabulary to become more diverse, in its structure". It is precisely the need and demand for this style counterpoint to reality, occurrences, opinions, etc. that gives such value to the antonym. This presence in the lexicon of the antonym is done due to the emergence of new units such as: non-bureaucratic (from the noun bureaucratic). This is done through word-production models of the Albanian language.

Antonym is also important in the process of designing signs and icons such as traffic lights, as well as visual art works of various kinds.

According to J.Thomai antonyms serve as:

- Explanatory tool for dictionaries in addition to school texts, in teaching a foreign language, etc.

- Powerful tools used in lectures expression of different styles of literary language, in fiction. Through their example antithesis built $F$. Noli in "Dead in exile" poem:

For he loved you when they hated you,

For he wept when they derided you,

For he clothed you when they denuded you,.

- Used in political pamphlets, humorous and satirical writings, etc., where its typified, social surroundings etc.

- In summary, we can say that in terms of the role of antonyms it can be said that it serves significantly in some respects as we have listed below:

- Antonym serve as a good explanation of the lexicography in the definitions of words in the dictionary.

- They also appear as a good tool for forming the antithesis in literature. Also, the figurative antonym meaning are expressive tools in literature.

- For the word-formation linguistic ability it can be said that they play a significant role in enriching the language and vocabulary.

- Importance of antonym observed in the process of mother language acquisition and of the second language, and on our specific case, that of the English language.

\section{Discursive Functions of Antonyms}

Antonym semantic differences make them perform opposing functions in discourse, which functions in association with these syntactic frames in which antonyms are coordinated. Researcher as Metinnger and Fellbaum, Jones through their research have categorized the 56 couple's contextual coordination canonical antonyms include names, adverbs, verbs, adjectives. These are harvested from the corpus of British newspapers. Jones identifies eight main functions, two dominating in most of the cases, precisely coordinated function and the auxiliary.

The coordinated function which Jones calls antonym of incorporation or depletion showed in an axle. Example:

The Albion manager would neither confirm nor deny Goodman's impeding departure.

The aid function is as widespread as much as the coordinated one in Jones's study. Antonyms auxiliary also play an important role in countering the discourse modelled using an association or other antonym pairs. Hence aide function couple which are used to emphasize the difference between the limbs of another couple. Example:

It is meeting public need not private greed

Presence of aid strengthens couple dichotomous nature of the couple next companion. Sometimes accompanying the couple cannot be seen as antonymic if not accompanied by the couple. Example:

Kennedy dead is more interesting than Clinton alive.

The other six functions as Jones classifies as insignificant, also adds a category which are called "the left overs". Jones thinks that some of these categories may be classified as a subcategory of the main functions. Other models or categories besides the coordination and auxiliary functions are also comparable, distinct, transitional and retracted. Comparative function Example:

More $X$ than $Y$

$X$ Rather than $Y$

Sometimes I feel more masculine than feminine. 
Distinctive function notes the differences between antonyms:

This blurred the distinction between fact and fiction.

Transitional function notes the change of status or position:

Even stronger currency turned soft.

Denying function expressed through a limb is used in the form of negation in order to emphasize another form of positive phrases:

The public has cause for pessimism, not optimism.

\section{Conclusion}

It is important to underline in the end the fact that antonyms are an essential part of the daily communication in different circumstances. As the examples above showed, antonyms are used to differentiate meanings of sentences and their structures and are a source of new means of communication. Even though they are linguistically explained, every second language learner of English language must be aware when using them and also very attentive when trying to get their meaning. Due to the use in journalism and all kinds of media, which a very good source of learning a second language, in English language they are very much utilised for different modifications of expressions. The way they are used are different in many languages and the importance, without noticing the proper value sometimes, is increased when using the language daily.

\section{Bibliography}

Carita Paradis , Caroline Willners, (2006), Antonymy and Negation : The boundless hypothesis, Journal of Pragmatics, (Shembulli i fjalisë i marrë nga Thomas Jefferson)

Fellbaum, C. (Ed.).(1998).WordNet: An electronic lexical database.Cambridge, MA: MITPress

Fellbaum, C. (1995). Co-occurrence and antonymy. International Journal of Lexicography,

Giora, R., Heruti V.,Metuki, M. \&F.Ofer.(2009).When we say no we mean no: Onnegation in vision and language.Journal of Pragmatics Jani Thomai (1974), "Leksikologjia e Gjuhës Shqipe" Tiranë

Jerome Kagan (1984), The Nature of the Child. New York: Basiç Books

John Lyons (1977), Semantics. Cambridge: Cambridge University Press

Lloyd, G. E. R.(1966).Polarity and analogy. Cambridge: Cambridge University press

Mettinger, A. (1994).Aspects of semantic opposition. Oxford: Clarendon Press

Miço Samara (1985) Çështje të Antonimisë në gjuhën shqipe, Tiranë

Steven Jones ( 2002), Antonymy: a Corpus-based Perspective. London: Routledge

Steve Jones. \&M. L.Murphy.(2005). Using corpora to investigate antonym acquisition. International Journal of Corpus Linguistics

William Croft, D., Alan Cruse, (2004), Journal of Pragmatics 